Peer review: This article has been subject to a double-blind peer review process

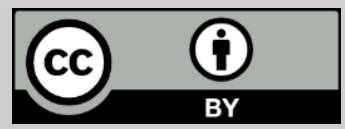

Copyright notice: This article is issued under the terms of the Creative Commons Attribution License, which permits use and redistribution of the work provided that the original author and source are credited.

You must give appropriate credit (author attribution), provide a link to the license, and indicate if changes were made. You may do so in any reasonable manner, but not in any way that suggests the licensor endorses you or your use. You may not apply legal terms or technological measures that legally restrict others from doing anything the license permits.

https://creativecommons .org/licenses/by/4.0/

\section{Problems of Reading Comprehension in Learning Chinese As A Second Language Among Undergraduates of Chinese Studies in Nnamdi Azikiwe University, Awka, Nigeria}

\author{
Victor C. Eze ${ }^{1}$, Oluchi StellaMaris Ejiofor ${ }^{2}$ \\ ${ }^{1}$ Communication and Language Arts Department, University of Ibadan, Nigeria \\ ${ }^{2}$ Chinese Studies Department, Nnamdi Azikiwe University, Awka, Nigeria \\ Correspondence: viccjohnson@gmail.com
}

\begin{abstract}
Several Chinese language teaching and learning centres are being established in Nigeria and around the world. There are Chinese government-funded institutions such as the Confucius Institutes in addition to Chinese language courses being taught through universities, colleges, private institutions as well as individual tutoring services. Learning a second language involves physical, intellectual and emotional commitment in order to successfully understand and interpret linguistic messages. However, certain problems could hinder understanding while learning a second language like Mandarin (Chinese Language). This study investigated the problems of reading comprehension in learning Chinese as a second language in Nigeria among students of Chinese Studies Department in Nnamdi Azikiwe University, Awka. Schemata theory of reading comprehension was employed as the theoretical framework of this research. The study surveyed fifty (50) Chinese Studies students by administering copies of questionnaire on them. Findings of this study revealed that the major problems students face in the study of Chinese language as foreign language are lack of adequate knowledge of Chinese vocabularies, reading stress and anxiety, wrong reading habits and lack of adequate infrastructures for reading. This study suggests that the government, the university authorities and language schools should provide adequate reading facilities to aid proper reading comprehension. Also, the language students should be counselled in order to diagnose their reading problems for appropriate solution.
\end{abstract}

Keywords: Chinese as a Second Language, reading comprehension, Nigeria, China, SLA, second language acquisition, Mandarin 


\section{Introduction}

Language is a very important means of communication. It is very difficult to think of a society without language. It sharpens the thoughts and ideas of people and controls their activities. It is a carrier of civilization and culture. In the case of the mother tongue, the child learns it easily, due to the favourable environment and by the great amount of exposure to the language. But learning a second language requires conscious efforts and there are factors that affect the process of learning a second language, including attitude, self-confidence, motivation, duration of exposure to the language, classroom conditions, environment, family background, and availability of competent teachers (Verghese, 2009). The successful acquisition of a second language seems to some extent, contingent upon learners' views of the language learning environment, the learning situation, and how they view the target language and its speakers (Narayan et al., 2008). Like the environment and attitude, teacher's competence is also a factor that affects the second language learning. It is expected that a language teacher should be proficient in the language; the teacher's knowledge of and expertise in methods and techniques of language teaching should be of a reasonably high standard (Verghese, 2009).

Chinese as a foreign or second language refers to the studying of Chinese language by non-native speakers. There is an increasing interest in the learning of Chinese (Mandarin) as a second language globally. It is worthy to note that the teaching of Chinese both in China and outside of it has been an age long practice, dating back to 16th century. According to Liu (2011), about 670,000 people took Chinese Proficiency Test overseas in 2010. Many other countries are embracing the learning of Chinese languages. According to the BBC (2006), there was about a $57 \%$ increase in the number of English students who are taking Advanced Level (A Levels) exams in Chinese; with Brighton College, UK making Chinese one of their key [compulsory] subjects for study in 2006.

According to Lewis, Paul, Simons and Fennig (2015) the Chinese language family is the largest family in the world with around 1,197,000,000 total speakers. Lewis et al.'s study (2015) shows that the Chinese language family is separated into thirteen groups with the Mandarin Chinese group being the largest, with 848 million native speakers. Even when focusing solely on Mandarin Chinese it is still the most widely used language, by over double, with Spanish coming in as the second most spoken language in the world at 399 million speakers. Note that these statistics only consider native speakers of the language. Speaking Mandarin could, theoretically, allow one to communicate directly with the most native speakers. While the reach of Mandarin is quite large it goes beyond just 
communicating to a large population. Mandarin is the sole official language of the People's Republic of China and Taiwan. It is also one of the four official languages of the Republic of Singapore and one of the six official languages of the United Nations. As such, Mandarin can be used to communicate with these nations and organisations at various levels.

China's status as an emerging world power, with a successful and expanding economy, presents a large opportunity for outsiders to benefit by engaging with different entities of the Chinese economy. Mandarin offers a better ground of understanding for outsiders to the country's economic community. Given the current opportunities and widespread use of the language the time for non-native speakers to learn Chinese, specifically Mandarin Chinese, has arguably never been better. Although the time is right for learning Chinese and many people are learning it, it is not without difficulties as it is considered one of the world's most difficult languages for non-native speakers to become proficient in, especially native English speakers. This study investigates the difficulties of reading comprehensions in the process of learning Chinese as a second language.

\section{Statement of the Problem}

Many views have arisen with respect to the problems that emanate in learning a second language. The most common cause of the problems faced by a learner of the Chinese language is the existence of inherent structure of their first language. A central theme in second language research is that of inter language, the idea that the language learners use is not simply the result of differences between the languages that they already know and the language that they are learning, but that is a complete system on its own with its own systematic rules. However, languages that a learner already knows can have a significant influence on the process of learning a new one. This influence is called language transfer. Thus, learners of new languages face a series of problems in the course of language learning. Underscoring the problems of learning Chinese as foreign language, Spencer (2015: 33) states:

Mandarin Chinese is an extremely complicated language with an ever-growing presence in the world. However, second language learners of Mandarin Chinese must contend with numerous difficulties on the journey to second language acquisition. Firstly, like learners of all foreign languages they must deal with general issues regarding SLA ${ }^{i}$, such as stress, anxiety, different task types, speed related difficulties, vocabulary retention, and various other problems. Secondly, learners of Chinese also have to deal with many issues specific to Chinese, such as the many morphological differences 
between Chinese and other languages, acquisition of tones, and the complexity of the Chinese writing system.

Although some researchers have carried out investigations on various problems of learning Chinese as a second language, their main focus has been on correct pronunciation, inability to understand or comprehend new words, problems of writing Chinese characters and inadequate listening skills. Based on the foregoing considerations, this research investigates the problems which Chinese language learners encounter while reading Chinese comprehensions among the undergraduates of Chinese studies department in Nnamdi Azikiwe University, Awka, Anambra State, Nigeria. Very few studies have assessed students of Chinese Studies students and their language acquisition processes in Nigeria. This study contributes to literature in that regard.

\section{Research Questions}

1. What are the reading problems encountered by undergraduates of Chinese Studies in Nnamdi Azikiwe University, Awka, Nigeria?

2. To what extent does insufficient knowledge of Chinese vocabulary affect reading comprehension among undergraduates of Chinese Studies in Nnamdi Azikiwe University, Awka, Nigeria?

3. To what extent does anxiety/stress affect the understanding of reading Chinese comprehensions among students in Nnamdi Azikiwe University, Awka, Nigeria?

4. How does lack of adequate Chinese reading infrastructures in the school affect the reading habit of Chinese learners in Nnamdi Azikiwe University, Awka, Nigeria?

\section{Literature Review}

The ultimate goal of any research into second language is to achieve an understanding of the concept of reading. For all students, foreign language learners in particular, reading has been the main channel for acquiring academic knowledge (Akbari, Ghonsooly, Ghazanfari \& Shahriari, 2017). The problems of reading in studying a second language have received a larger attention over time. Empirical research has attempted to account for variables detailed by second language reading theories and provide an insight into second language reading problems. This review focuses on various studies on the problems of reading in a second language. Several scholars have extensively written and conducted research on reading comprehension and problems associated with it. For instance, Graham and 
Bellert (2009:71), in the study titled Reading comprehension difficulties experienced by students with learning disabilities, noted that students with learning disabilities face various problems with reading comprehension in terms of (a) using background knowledge appropriately; (b) decoding and word recognition; (c) vocabulary knowledge; (d) fluency; (e) strategy use and metacognitive skills; and ( $f$ ) differentiating between common text structures.

Highlighting the importance of vocabularies in reading comprehension, some scholars have found that poor performance in reading comprehension is often associated with gaps in the knowledge of vocabularies and lack of attention to developing language in most schools (Scott, Jamieson-Noel \& Asselin, 2003; Watts, 1995).

According to Shirin (2012), the consensus among reading educators and experts is that reading is a complex, interactive process that involves features of readers, texts and tasks. In the reading process, the reader is an active participant, constructing meaning from clues found in printed text (Bernhardt, 1991; Grabe, 1991). In other words, meaning is not inherent in texts, rather texts have the potential for meaning. Reading is also an individual process that often entails different interpretations for different readers. Till now, the focus of research revolves on whether reading in one's first language (L1) is similar or different; if similar strategies are used in reading in $\mathrm{L} 1$ and $\mathrm{L}^{\mathrm{ii}}$. Researchers try to examine any relationship between $L 1$ and $L 2$ reading processes. Another hot issue is whether reading in L2 is a reading or a language problem; if the strategies used by proficient L1 readers are transferable to reading in the $L 2$. Both reading in $L 1$ and $L 2$ involve the use of various strategies that assist readers in understanding what is read. Studies show that both readers' L1 reading ability and L2 language proficiency contribute to L2 reading comprehension (Carrell, 1991; Bosser, 1992).

Zhang and Anual (2008) investigated the role of vocabulary in reading comprehension among secondary school students learning English in Singapore. The study was carried out to ascertain the role of vocabulary in reading comprehension, which was based on the assumption students and teachers usually state that vocabulary is the biggest problem in reading. The scholars surveyed 37 year 4 secondary school students iii in a neighbourhood school in Singapore in their vocabulary knowledge vis-àvis their reading comprehension and summary abilities. Findings of the study showed that the more vocabulary students know, the better their performance in reading competition.

Also, Ahmadi gilani et al (2012) state that a student's recognition of a text is dependent on both the student's linguistic knowledge, his/her general knowledge of the world and the degree to which that knowledge is 
employed during processing. This refers to both knowledge and ability to contextualize it. Thus, reading comprehension is an interactive process between the reader and the text being read. The foregoing [ideas] align with the view of Carrel and Eisterhold (1983) that reading comprehension involves one's knowledge of the world, which may be culturally based and culturally biased. In other words, having background knowledge in a psycholinguistic model in learning second language offers a positive background for a better reading comprehension session.

Lau and Chan (2003) assessed the reading comprehension ability and the motivation variables of 83 good readers and 76 poor readers and found that the poor readers scored lower than good readers in employing all reading strategies and, especially in the use of sophisticated cognitive and metacognitive approaches. The scholars also found that poor readers had low internal motivation in reading that good readers. Though the employment of reading strategies had the strongest relation with reading comprehension, intrinsic motivation and strategy attribution could enable reading development through their positive relations with strategy use (Lau and Chan 2003:1).

Akbari, Ghonsooly, Ghazanfari and Shahriari (2017) examined 230 Iranian English language learners to find out the connection between L2 and L1 reading attitudes, and the degree $L 2$ reading attitudes contribute to $L 2$ reading achievement in an Iranian $\mathrm{EFL}^{\mathrm{iv}}$ context. The study found that $\mathrm{L} 1$ reading attitude has a strong correlation with $L 2$ reading attitude, and that L2 reading attitude is significant for L2 reading achievement; thus developing a positive attitude among L2 learners and L2 readers is important.

Savic (2015) looked at the reading difficulties of young learners within an English as foreign language formal school setting in Serbia. The research took into consideration the fact that reading difficulties have negative effect on learners' self-esteem, attitude, motivation, confidence, academic and career prospects, and that the prevention of reading difficulties is an issue which requires effective action. The study involved 502 learners, aged 11, drawn from six state primary schools located in five geographically distant towns of Serbia. It found that reading difficulties in early EFL reading may have been the result of adverse effects of some individual and contextual factors, like poor linguistic and strategic competences of young learners, negative transfer of L1 literacy, inappropriate teaching approach, and insufficient exposure to $L 2$ texts. A taxonomy of reading difficulties was complied, comprising $25 \mathrm{~L} 2$ reading difficulties 
Lau (2006) investigated the difference between Chinese good and poor readers in their strategy use by using a think-aloud method. Eight grade 7 students in Hong Kong ${ }^{v}$, four good readers and four poor readers, received a think-aloud task and an interview in the study. The study found that Chinese good readers employed more reading strategies and had better ability and knowledge of strategy use than the poor readers. The study also found that in addition to the cognitive deficiencies, poor readers were also found to have poorer intrinsic motivation than did good readers. This study underscored the fact that the combined problems of poor reading ability and motivation made it hard for poor reader to process the text at a higher level and thus easily gave up reading when they are faced with difficulties.

Anxiety and Stress were also pointed out as part of the problems in reading. For instance, Zhao, Dynia and Guo (2013) accessed the foreign language ( $\mathrm{FL}$ ) reading anxiety level of English-speaking university students learning Chinese as a foreign language in the United States ${ }^{\mathrm{vi}}$. The study measured data from two anxiety measures, a background information questionnaire, and an email interview. It found that learners of Chinese experienced a level of FL reading anxiety similar to general FL anxiety. The $\mathrm{FL}$ reading anxiety was negatively linked with $\mathrm{FL}$ reading performance among Elementary Level I and Intermediate Level students but not among Elementary Level II students. Unfamiliar scripts, unfamiliar topics, and worry about comprehension were identified as the major sources of FL reading anxiety. The study showed that reading anxiety was a major problem for learners of Chinese whose native language was English.

Zhou (2017) investigated the foreign language reading anxiety of learners of Chinese as foreign language $\mathrm{FL}$ in the United States ${ }^{\mathrm{vii}}$. It surveyed the background information of respondents and also interviewed them and found that there was no significant difference in reading anxiety level among four course levels. The study also found that Chinese L2 learners had a medium level of reading anxiety. It was noted that worries associated with comprehension, unfamiliar topics, unknown pronunciation, and feeling uncomfortable reading aloud were identified as major sources of FL reading anxiety (ibid).

Hidayati (2018) examined the problems faced by the first-grade students of senior high school of SMAN 1 Darussalam, Aceh Besar in reading comprehension. The findings of the study showed that many of the firstgrade students of SMAN 1 Darussalam, Aceh Besar had problems in answering main idea, making inference, and locating reference questions. The most difficult aspect encountered by the students was finding main idea questions, because the located main idea was difficult to find. According to Hidayati, it was discovered that based on the students' 
responses in questionnaire, they mostly had difficulties in understanding vocabulary, poor mastery of grammar, difficulties in understanding long sentences, a lack of media learning, less support from the family, and a lack of knowledge of strategies for reading comprehension.

Karanja (2015) tried to find out the extent to which reading problems affect the academic performance of secondary school student in public schools in Kiambus County, Kenya. Surveying both teachers of English and students, the study found students who had little difficulties with word substitution, omission, mispronunciation and addition scored high in their exam, while many of the teachers of English had problems in teaching reading. The study also found that $60 \%$ of the teachers did not conduct library lessons at all due to lack of library resources.

\section{Theoretical Framework}

This study is hinged on schema theory. Schema refers to an active organization of reactions or experiences (An, 2013). Gunning (1996) defines a schema as the organized knowledge that one already has about people, places, things, and events. Schema theory describes the interaction between what is in the text and how that information is shaped and stored by the reader. Its underlying assumption is that meaning does not lie solely in the print itself, but interacts with the cognitive structure or schemata already present in the reader's mind. Comprehension is making a sense out of text. It is a process of using reader's existing knowledge (schemata) to interpret texts in order to construct meaning. Many reading experts agree that the schema theory is one of the reasonable theories of human information processing.

Weng (2009:134) citing Clarke and Silberstein 1977 states that research has shown that reading is only incidentally visual. More information is contributed by the reader than by the print on the page. That is, readers understand what they read because they are able to take the stimulus beyond its graphic representation and assign it membership to an appropriate group of concepts already stored in their memories.

The implication of Schemata theory to reading comprehension is that all comprehension exercise entails the application of the reader's knowledge of the world as well (An, 2013 citing Anderson, 1977:39). According to Carrel and Eiserhold (1983), reading comprehension has a two-way operation which are from bottom up to the top and from the top down to the bottom of the hierarchy. Bottom-up processing is activated by specific data from the text, while top-down processing starts with general to confirm these predictions. These two kinds of processing are occurring simultaneously and interactively, which adds to the concept of interaction or comprehension between bottom-up and top-down processes. Thus, the 
reading problems readers face has some foundation on their past knowledge and experiences as defined by their schemata.

\section{Methodology}

This study employs descriptive research design. Descriptive design studies are mainly concerned with describing events as they are without any manipulation of what is being observed. Any study which seeks merely to find out 'what is' and describes it is descriptive. The design is suitable to ascertain the problems of reading on the learning and proficiency in Chinese language of the BA Chinese students of Nnamdi Azikiwe University, Awka, Anambra state. The population of this study comprised of year I to year IV (final year) Chinese studies students of Nnamdi Azikiwe University.

This study was carried out through purposive sampling technique which sets out to select samples that have the trait required for the research. The four levels of students in the department of Chinese studies were selected for this study excluding the Confucius Institute students. The total population for this study was fifty (50) students, comprising of twenty (20) students from year I, ten (10) students from year II, ten (10) students from year III and ten (10) students from year IV (final year). The main instrument for the data collection of this study was self-administered questionnaire which was divided into five sections; $A$ to $E$. Section $A$ of the questionnaire investigated the reading problems among respondents; Section $B$ investigated the knowledge of Chinese vocabulary among respondents; Section C focused on respondents' stress/anxiety level while reading Chinese comprehension; Section D captured respondents' reading habits and available reading infrastructure; and Section $E$ focused on the demography of respondents. 


\section{Results and Discussion of Findings}

The results of the analysis are presented in the sections below. Table 1 presents the demography of the respondents.

Table 1 Demographic Characteristics of the Respondents

\begin{tabular}{lllcc}
\hline & Variable & Measure & Frequency & Percent (\%) \\
\hline 1. Sex & Male & 19 & 38 \\
& & Female & 31 & 62 \\
2. & Age & Total & $\mathbf{5 0}$ & $\mathbf{1 0 0}$ \\
& $15-20$ years & 7 & 14 \\
& Marital Status & Total & $\mathbf{5 0}$ & $\mathbf{1 0 0}$ \\
3. & Single & 46 & 92 \\
& & Married & 3 & 6 \\
& & Separated & 1 & 2 \\
& & Total & $\mathbf{5 0}$ & $\mathbf{1 0 0}$ \\
4. Class Level in School & Year 1 & 13 & 26 \\
& & Year 2 & 19 & 38 \\
& & Year 3 & 16 & 16 \\
& & Year 4 & 10 & 20 \\
& & Total & $\mathbf{5 0}$ & $\mathbf{1 0 0}$ \\
\hline
\end{tabular}

Table 1 shows the demographic attributes of the respondents. The majority of the respondents (62\%) were female while the male respondents accounted for $38 \%$ of the total sample; many of the respondents 43 (86\%) fell within the age bracket of $21-25$ years; also, majority of the respondents 46 (92\%) were single while $6 \%$ were married, $2 \%$ were separated; most of respondents 19 (38\%) were in Year 2, 26\% of the respondents were in Year 1, 16\% of them were in Year 3 while $20 \%$ of the respondents were in Year 4.

\subsection{Presentation and Analysis of Research Questions}

This section presents answers to the research questions. The various research questions are presented together with data analysis and discussion of findings.

Research Question 1: What are the reading problems encountered by Chinese students in Nnamdi Azikiwe University, Awka, Nigeria?

This research question shows the various problems faced by undergraduate students of Chinese studies department, Nnamdi Azikiwe University, Awka, Nigeria, in terms of reading comprehension. Table 2 presents the responses from the respondents. 
Table 2 Reading Problems among Chinese Students in UNIZIK

\begin{tabular}{|c|c|c|c|c|c|}
\hline$S / N$ & Variable & $\begin{array}{l}\text { Yes } \\
F(\%)\end{array}$ & $\begin{array}{l}\text { No } \\
F(\%)\end{array}$ & $\begin{array}{l}\text { I Don't } \\
\text { Know } \\
\text { F (\%) }\end{array}$ & $\begin{array}{l}\text { Total } \\
\text { F (\%) }\end{array}$ \\
\hline 1. & $\begin{array}{l}\text { I have problem with } \\
\text { understanding Chinese } \\
\text { vocabulary }\end{array}$ & $\begin{array}{l}19 \\
(38 \%)\end{array}$ & $\begin{array}{l}30 \\
(60 \%)\end{array}$ & $\begin{array}{l}1 \\
(2 \%)\end{array}$ & $\begin{array}{l}50 \\
(100 \%)\end{array}$ \\
\hline 2. & $\begin{array}{l}\text { I have problem with } \\
\text { Chinese grammar }\end{array}$ & $\begin{array}{l}29 \\
(58 \%)\end{array}$ & $\begin{array}{l}20 \\
(40 \%)\end{array}$ & $\begin{array}{l}1 \\
(2 \%)\end{array}$ & $\begin{array}{l}50 \\
(100 \%)\end{array}$ \\
\hline 3. & $\begin{array}{l}\text { My school has good } \\
\text { Chinese library }\end{array}$ & $\begin{array}{l}17 \\
(34 \%)\end{array}$ & $\begin{array}{l}30 \\
(60 \%)\end{array}$ & $\begin{array}{l}3 \\
(6 \%)\end{array}$ & $\begin{array}{l}50 \\
(100 \%)\end{array}$ \\
\hline 4. & $\begin{array}{l}\text { My department has } \\
\text { reading laboratory }\end{array}$ & $\begin{array}{l}22 \\
(44 \%)\end{array}$ & $\begin{array}{l}25 \\
(50 \%)\end{array}$ & $\begin{array}{l}3 \\
(6 \%)\end{array}$ & $\begin{array}{l}50 \\
(100 \%)\end{array}$ \\
\hline 5. & $\begin{array}{l}\text { I have good sight for } \\
\text { reading Chinese } \\
\text { comprehension }\end{array}$ & $\begin{array}{l}38 \\
(76 \%)\end{array}$ & $\begin{array}{l}11 \\
(22 \%)\end{array}$ & $\begin{array}{l}1 \\
(2 \%)\end{array}$ & $\begin{array}{l}50 \\
(100 \%)\end{array}$ \\
\hline 6. & $\begin{array}{l}\text { Stress and anxiety affect } \\
\text { my Chinese reading } \\
\text { comprehension }\end{array}$ & $\begin{array}{l}23 \\
(46 \%)\end{array}$ & $\begin{array}{l}18 \\
(36 \%)\end{array}$ & $\begin{array}{l}9 \\
(18 \%)\end{array}$ & $\begin{array}{l}50 \\
(100 \%)\end{array}$ \\
\hline 7. & $\begin{array}{l}\text { Poor grasp of Chinese } \\
\text { culture affects my } \\
\text { understanding }\end{array}$ & $\begin{array}{l}23 \\
(46 \%)\end{array}$ & $\begin{array}{l}22 \\
(44 \%)\end{array}$ & $\begin{array}{l}5 \\
(10 \%)\end{array}$ & $\begin{array}{l}50 \\
(100 \%)\end{array}$ \\
\hline
\end{tabular}

Table 2 shows that majority of the respondents or $30(60 \%)$ stated that they did not have problem with understanding Chinese vocabulary; many of the respondents or 29 (58\%) agreed that they have problems with Chinese grammar; 30 (60\%) of the respondents stated that their school does not have a good Chinese library; 25 (50\%) of the respondents stated that their school had no reading laboratory. Many of the respondents, 38 (76\%), stated that they have good sight for reading Chinese comprehension, while 11 (22\%) stated that they have sight problem. 23 (46\%) of respondents agreed that stress and anxiety affected their Chinese reading comprehension. 23 (46\%) of respondents noted that poor grasp of Chinese culture affected their understanding, while 22 (44\%) of the respondents stated their poor grasp of Chinese culture did not affect their understanding.

Findings from the study showed that the reading problems among undergraduate students of Chinese Studies, UNIZIK viii are: Chinese grammar, lack of good Chinese library, lack of reading laboratory, stress and anxiety and poor grasp of Chinese culture. While many of the respondents do not have a problem with understanding Chinese vocabulary, the students face more problems that could hamper their understanding of reading Chinese comprehension. 
The above findings are in line with the observation of Graham and Bellert (2009:71) which holds that some of the reading comprehension problems are (a) using background knowledge appropriately; (b) decoding and word recognition; (c) vocabulary knowledge; (d) fluency; (e) strategy use and metacognitive skills; and (f) differentiating between common text structures. Also, several other scholars have highlighted vocabulary deficiency as a problem in reading comprehension (Scott, Jamieson-Noel \& Aselin, 2003; Watts, 1995). Similarly, some other researchers noted that stress and anxiety constitute problems in reading comprehension exercises (Zhao, Dynia \& Guo, 2013; Zhou, 2017; Hidayati, 2018). In addition, Karanja (2015) suggested that inadequate Chinese reading infrastructures was a problem in reading comprehension. In all, the reading problems among undergraduate students of Chinese Studies at the Nnamdi Azikiwe University, Awka could affect students' understanding of Chinese comprehension. The students will perform better when the problems are solved.

Research Question 2: To what extent does insufficient vocabulary knowledge affect the understanding of reading comprehensions among Chinese students in Nnamdi Azikiwe University, Awka?

This research question shows the degree to which insufficient vocabulary knowledge among undergraduate students of Chinese studies department, Nnamdi Azikiwe University, Awka affect their understanding of reading comprehension. Table 3 presents the responses from the respondents. 
Table 3 Degree of Respondents' Knowledge of Chinese Vocabulary and Understanding of Reading Comprehension

\begin{tabular}{|c|c|c|c|c|c|c|}
\hline$S / N$ & Variable & $\begin{array}{l}\text { VGE } \\
F(\%)\end{array}$ & $\begin{array}{l}\text { GE } \\
F(\%)\end{array}$ & $\begin{array}{l}\text { LE } \\
F(\%)\end{array}$ & $\begin{array}{l}\text { NE } \\
F(\%)\end{array}$ & $\begin{array}{l}\text { Total } \\
\text { F (\%) } \\
\end{array}$ \\
\hline 1. & $\begin{array}{l}\text { I learn new Chinese } \\
\text { words always from } \\
\text { my teacher }\end{array}$ & $\begin{array}{l}34 \\
(68 \%)\end{array}$ & $\begin{array}{l}14 \\
(28 \%)\end{array}$ & $\begin{array}{l}2 \\
(4 \%)\end{array}$ & $\begin{array}{l}-- \\
(--)\end{array}$ & $\begin{array}{l}50 \\
(100 \%)\end{array}$ \\
\hline 2. & $\begin{array}{l}\text { I learn new Chinese } \\
\text { words always from } \\
\text { dictionary }\end{array}$ & $\begin{array}{l}32 \\
(64 \%)\end{array}$ & $\begin{array}{l}13 \\
(26 \%)\end{array}$ & $\begin{array}{l}4 \\
\text { (8\%) }\end{array}$ & $\begin{array}{l}1 \\
(2 \%)\end{array}$ & $\begin{array}{l}50 \\
(100 \%)\end{array}$ \\
\hline 3. & $\begin{array}{l}\text { I prefer reading } \\
\text { comprehension in } \\
\text { Chinese language }\end{array}$ & $\begin{array}{l}7 \\
(14 \%)\end{array}$ & $\begin{array}{l}18 \\
(36 \%)\end{array}$ & $\begin{array}{l}23 \\
(46 \%)\end{array}$ & $\begin{array}{l}2 \\
(4 \%)\end{array}$ & $\begin{array}{l}50 \\
(100 \%)\end{array}$ \\
\hline 4. & $\begin{array}{l}\text { I understand } \\
\text { Chinese words on } \\
\text { their own }\end{array}$ & $\begin{array}{l}13 \\
(26 \%)\end{array}$ & $\begin{array}{l}12 \\
(24 \%)\end{array}$ & $\begin{array}{l}19 \\
(38 \%)\end{array}$ & $\begin{array}{l}6 \\
(12 \%)\end{array}$ & $\begin{array}{l}50 \\
(100 \%)\end{array}$ \\
\hline 5. & $\begin{array}{l}\text { I understand } \\
\text { Chinese words in } \\
\text { comprehension } \\
\text { passages }\end{array}$ & $\begin{array}{l}8 \\
(16 \%)\end{array}$ & $\begin{array}{l}25 \\
(50 \%)\end{array}$ & $\begin{array}{l}15 \\
(30 \%)\end{array}$ & $\begin{array}{l}2 \\
(4 \%)\end{array}$ & $\begin{array}{l}50 \\
(100 \%)\end{array}$ \\
\hline
\end{tabular}

Table 3 shows that most of the respondents 48 (96\%) stated that to a great extent they learned new Chinese words always from their teacher, while $2(4 \%)$ noted that to a little extent they learned new Chinese words always from their teacher. 45 (90\%) of the respondents stated that to a great extent they always learned new Chinese words from a dictionary, while few of the respondents, $4(8 \%)$, noted that to a little extent they always learned new Chinese words from a dictionary. 25 (50\%) of the respondents stated that to a great extent they preferred reading comprehension in Chinese Language, while $23(46 \%)$ stated that to a little extent they preferred reading comprehension in the Chinese Language. 25 (50\%) of the respondents noted that to a great extent they understood Chinese words on their own, while 19 (38\%) stated that to a little extent they understood Chinese words on their own. 33 (66\%) of the respondents stated that to a great extent they understood Chinese words in comprehension passages, while 15 (30\%) noted they understood Chinese words in comprehension passages. In addition, factor analysis exposed that there is a significant relationship between vocabulary knowledge and the understanding of reading comprehension (Table 4). 
Table 4 KMO and Bartlett's Test

\begin{tabular}{lll}
\hline Kaiser-Meyer-Olkin Measure of Sampling Adequacy & .638 \\
& Approx. Chi-Square & 52.805 \\
Bartlett's Test of Sphericity & df & 10 \\
& Sig. & .000 \\
\hline
\end{tabular}

Findings from the study showed that to a great extent the undergraduate students of Chinese studies department understand or learn new Chinese words from their dictionary and teachers. The words they have learned in this way help the students in understanding Chinese words, both when encountered alone and also when they are studying reading comprehension passages.

Supporting the findings of this study, some scholars have found that poor performance in reading comprehension is often associated with gaps in the knowledge of vocabularies and lack of attention to developing language in most schools (Scott, Jamieson-Noel \& Asselin, 2003; Watts, 1995). In addition, the findings of this study are supported by the submission of Zhang and Anual (2008) which confirmed that that the more vocabulary students know, the better their performance in reading comprehension. Corroborating the findings of this study, Hidayati (2018) found that understanding vocabulary, poor mastery of grammar and the difficulty in understanding long sentences constitute problems in reading comprehension. In all, to a great extent, undergraduate students of Chinese Studies in the Nnamdi Azikiwe University, Awka need to have a good grasp of Chinese vocabulary in order to understand Chinese comprehension. The students' performance may improve if they possess a good knowledge of Chinese vocabulary.

Research Question 3: To what extent does stress/anxiety affect the understanding of reading Chinese comprehensions among students in Nnamdi Azikiwe University, Awka?

This research question shows the degree to which stress and anxiety affect the understanding of reading Chinese comprehension among undergraduate students of Chinese studies department, Nnamdi Azikiwe University, Awka. Table 5 presents the responses from the respondents. 
Table 5

Degree of Respondents' Stress/Anxiety Level and Understanding of Comprehension

\begin{tabular}{|c|c|c|c|c|c|c|}
\hline$S / N$ & Variable & $\begin{array}{l}\text { VGE } \\
\text { F (\%) }\end{array}$ & $\begin{array}{l}\text { GE } \\
\text { F (\%) } \\
\end{array}$ & $\begin{array}{l}\text { LE } \\
F(\%) \\
\end{array}$ & $\begin{array}{l}\text { NE } \\
\text { F (\%) } \\
\end{array}$ & $\begin{array}{l}\text { Total } \\
\text { F (\%) } \\
\end{array}$ \\
\hline 1. & $\begin{array}{l}\text { I am always } \\
\text { stressed while } \\
\text { reading Chinese } \\
\text { comprehensions }\end{array}$ & $\begin{array}{l}17 \\
(34 \%)\end{array}$ & $\begin{array}{l}15 \\
(30 \%)\end{array}$ & $\begin{array}{l}13 \\
(26 \%)\end{array}$ & $\begin{array}{l}5 \\
(10 \%)\end{array}$ & $\begin{array}{l}50 \\
(100 \%)\end{array}$ \\
\hline 2. & $\begin{array}{l}\text { I am always } \\
\text { anxious while } \\
\text { reading Chinese } \\
\text { comprehensions }\end{array}$ & $\begin{array}{l}19 \\
(38 \%)\end{array}$ & $\begin{array}{l}17 \\
(34 \%)\end{array}$ & $\begin{array}{l}11 \\
(22 \%)\end{array}$ & $\begin{array}{l}3 \\
(6 \%)\end{array}$ & $\begin{array}{l}50 \\
(100 \%)\end{array}$ \\
\hline 3. & $\begin{array}{l}\text { Stress affects my } \\
\text { understanding of } \\
\text { Chinese } \\
\text { comprehensions }\end{array}$ & $\begin{array}{l}20 \\
(40 \%)\end{array}$ & $\begin{array}{l}17 \\
\text { (34\%) }\end{array}$ & $\begin{array}{l}9 \\
(18 \%)\end{array}$ & $\begin{array}{l}4 \\
(8 \%)\end{array}$ & $\begin{array}{l}50 \\
(100 \%)\end{array}$ \\
\hline 4. & $\begin{array}{l}\text { Anxiety affects my } \\
\text { understanding of } \\
\text { Chinese } \\
\text { comprehensions }\end{array}$ & $\begin{array}{l}16 \\
(32 \%)\end{array}$ & $\begin{array}{l}18 \\
(36 \%)\end{array}$ & $\begin{array}{l}13 \\
(26 \%)\end{array}$ & $\begin{array}{l}3 \\
(6 \%)\end{array}$ & $\begin{array}{l}50 \\
(100 \%)\end{array}$ \\
\hline
\end{tabular}

Table 5 shows that most of the respondents $32(64 \%)$ stated that to a great extent they are always stressed while reading Chinese comprehensions, while $13(26 \%)$ of the respondents stated that to a little extent they are always stressed while reading Chinese comprehensions. 36 (72\%) of the respondents noted that to a great extent they are always anxious while reading Chinese comprehensions, while 11 (22\%) of the respondents noted that to a little extent they are always anxious while reading Chinese comprehensions. 37 (74\%) of the respondents stated that to a great extent their stress affected their understanding of Chinese comprehensions, while $13(26 \%)$ of the respondents stated that to a little extent stress affected their understanding Chinese comprehensions. 34 (68\%) of the respondents stated that, to a great extent, anxiety affected their understanding of Chinese comprehension, while 13 (26\%) of the respondents stated that to a little extent anxiety affected their understanding of Chinese comprehension. In addition, factor analysis exposed that there is a significant relationship between stress/anxiety and the and the understanding of reading comprehension (Table 6).

Table 6 KMO and Bartlett's Test

\begin{tabular}{lll}
\hline Kaiser-Meyer-Olkin Measure of Sampling Adequacy & .724 \\
& Approx. Chi-Square & 95.071 \\
\multirow{3}{*}{ Bartlett's Test of Sphericity } & df & 6 \\
& Sig. & .000 \\
\hline
\end{tabular}


Findings from the study showed that to a great extent stress and anxiety affect the understanding of reading Chinese comprehension among undergraduate students of Chinese Studies in Nnamdi Azikiwe University. Thus, to a great extent, stress and anxieties affect the understanding of reading Chinese comprehension among students.

The above findings are in line with the findings of Zhao, Dynia and Guo (2013) in the study which examined foreign language reading anxiety level of English-speaking university students learning Chinese as foreign language in the United States. The scholars found that anxiety and accompanying stress affected the reading comprehension of students studying Chinese language. Unfamiliar scripts, unfamiliar topics, and worry about comprehension were identified as the major sources of $\mathrm{FL}$ reading anxiety (ibid, 2013). In addition, Zhou (2017) underscores that that worries associated with comprehension, unfamiliar topics, unknown pronunciation, and feeling uncomfortable reading aloud were identified as major sources of FL reading anxiety. All the aforementioned scholars agree that anxiety and stress constitute major problems in reading Chinese comprehension. In all, students who face stress and anxiety while reading Chinese comprehension will find it difficult to understand the passage. Understanding how to limit stress and anxiety could aid adequate understanding of Chinese comprehension.

Research Question 4: How does lack of adequate Chinese reading infrastructures in the school affect the reading habit of Chinese learners in UNIZIK?

This research question shows how lack of adequate Chinese reading infrastructures in the school affects the reading habit of undergraduate students of Chinese studies in UNIZIK. Table 7 presents the responses from the respondents. 
Table 7

Reading Infrastructure and Reading Habit of Respondents

\begin{tabular}{|c|c|c|c|c|c|}
\hline$S / N$ & Variable & $\begin{array}{l}\text { Yes } \\
\text { F (\%) }\end{array}$ & $\begin{array}{l}\text { No } \\
\text { F (\%) }\end{array}$ & $\begin{array}{l}\text { I Don't } \\
\text { Know F } \\
\text { (\%) }\end{array}$ & $\begin{array}{l}\text { Total } \\
\text { F (\%) }\end{array}$ \\
\hline 1. & $\begin{array}{l}\text { Lack of Chinese books in } \\
\text { the library affects my } \\
\text { reading habit }\end{array}$ & $\begin{array}{l}22 \\
(44 \%)\end{array}$ & $\begin{array}{l}23 \\
(46 \%)\end{array}$ & $\begin{array}{l}5 \\
(10 \%)\end{array}$ & $\begin{array}{l}50 \\
(100 \%)\end{array}$ \\
\hline 2. & $\begin{array}{l}\text { Lack of Chinese library } \\
\text { affects my reading habit }\end{array}$ & $\begin{array}{l}24 \\
(48 \%)\end{array}$ & $\begin{array}{l}21 \\
(42 \%)\end{array}$ & $\begin{array}{l}5 \\
(10 \%)\end{array}$ & $\begin{array}{l}50 \\
(100 \%)\end{array}$ \\
\hline 3. & $\begin{array}{l}\text { Lack of Chinese reading } \\
\text { sessions affects my } \\
\text { reading habit }\end{array}$ & $\begin{array}{l}26 \\
(52 \%)\end{array}$ & $\begin{array}{l}20 \\
(40 \%)\end{array}$ & $\begin{array}{l}4 \\
(8 \%)\end{array}$ & $\begin{array}{l}50 \\
(100 \%)\end{array}$ \\
\hline 4. & $\begin{array}{l}\text { My Chinese teacher's } \\
\text { ability affects my reading } \\
\text { habit }\end{array}$ & $\begin{array}{l}10 \\
(20 \%)\end{array}$ & $\begin{array}{l}36 \\
(72 \%)\end{array}$ & $\begin{array}{l}4 \\
(8 \%)\end{array}$ & $\begin{array}{l}50 \\
(100 \%)\end{array}$ \\
\hline
\end{tabular}

Table 7 shows that 22 (44\%) of the respondents agreed that a lack of Chinese books in the library affected their reading habit, while $23(46 \%)$ of the respondents disagreed. 24 (48\%) of respondents affirmed that a lack of a Chinese library affected their reading habit, while 21 (42\%) of the respondents disagreed. 26 (52\%) of the respondents agreed that lack of Chinese reading sessions affected their reading habits, while $20(40 \%)$ of the respondents disagreed. $10(20 \%)$ of the respondents agreed that their Chinese teacher's ability affected their reading habits, while 36 (72\% of the respondents disagreed.

Findings from the study showed that lack of reading infrastructures affects the reading habit of Chinese learners in UNIZIK, due to lack of books in the library, lack of Chinese library and the absence of reading sessions in the department. The respondents' Chinese teacher's ability does not affect their reading habit.

The above findings are in line with the findings of Karanja (2015) in the study which investigated the reading problems that affect students. The researcher found that inadequate Chinese reading infrastructure affect the students. The same study observed that many of the teachers did not conduct lessons due to lack of library resources in the school. In all, students' reading habit is hampered by unavailability of books and lack of Chinese library. There is also the factor of no reading sessions available to help improve the reading habits of students. Putting adequate infrastructures in place could improve the reading habits of students. 


\section{Conclusion and Recommendations}

Researchers have investigated the various problems students face in reading comprehensions while learning Chinese as second language. This research was conducted in Nigeria and it investigated the problems of reading comprehension in studying Chinese as a second language among the undergraduates of Chinese Studies department in Nnamdi Azikiwe University, Awka, Anambra State. This study identified the various problems students face while reading Chinese comprehension and which appear somewhat generalizable to the students who are studying Chinese Language in Nigeria. This is based on the fact that they are likely to share the same socioeconomic circumstances and school terrain.

This study makes recommendation for various agents in the government and academic institutions. The government should adopt educational policies which will influence the lives of the students positively. This will include providing adequate infrastructures ranging from libraries, laboratories for reading and appropriate books. Academic scholars and institutions should embark on more training to ensure lecturers possess the skills needed that will translate positively into the educational lives of the students. More teacher-student counselling sessions should be mapped out by Chinese studies departments and other language study departments in order to identify how best to help students learn foreign languages.

Victor C. Eze is a doctoral student in the Communication
and Language Arts Department of University of Ibadan,
Nigeria. His research interests include China-African
relations, media framing, conflict/risk communication,
political communication and public diplomacy. He is a
member of International Communication Association (ICA)
and International Association for Media and
Communication Research (IAMCR).
Stellamaris Oluchi Ejiofor graduated with a First Class from
the Chinese Studies Department, Nnamdi Azikiwe
University, Awka, Nigeria. She attended Confucius Institute
at the same university and passed the highest level of The
Chinese Proficiency Exam (HSK6).

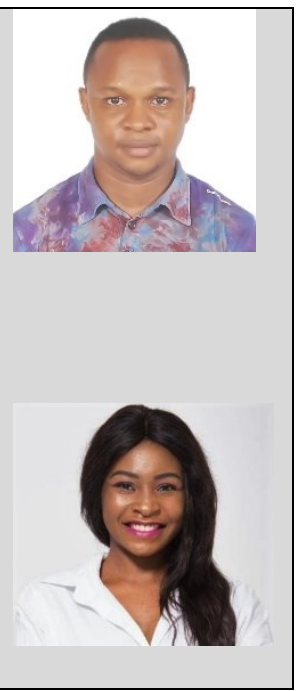




\section{References}

Ahmadi Gilani, M. R., Nizam Ismail, H. and Pourhossein Gilakjani, A., 2012. Impacts of Learning Reading Strategy on Student's Reading Comprehension Proficiency. The International Journal of Language learning and Applied Linguistics World, (IJLLALW). 1(1), December 2012.

Akbari, H., Ghonsooly, B., Ghazanfari, M. and Shahriari, H., 2017. Attitude Toward Reading: L1 or L2 or Both. SAGE Open. Available at: https://doi.org/10.1177/2158244017717303, [Accessed: 16 January 2019].

An, S., 2013. Schema Theory in Reading. Theory and Practice in Language Studies, 3(1), pp. 130-134. Available at: https://doi:10.4304/tpls.3.1.130134, [Accessed: 20 January 2019].

BBC., 2006. How hard is it to learn Chinese. Available at:

http://news.bbc.co.uk/2/hi/uk news/magazine/4617646.stm, [Accessed: 10 January 2019].

Bernhardt, E. B., and Kamil, M. L., 1995. Interpreting Relationships between L1 and L2 Reading: Consolidating the Linguistic Threshold and the Linguistic Interdependence Hypotheses. Applied Linguistics. 16(1), pp. 15-34.

Bossers, B., 1992. Reading in Two Languages: A Study of Reading Comprehension in Dutch as a Second Language and in Turkish as a First Language. Rotterdam: Drukkerij Van Driel.

Carrel, P. L., 1991. Second language reading: Reading ability or language proficiency? Applied linguistics, 12, pp. 159-179.

Carrell, P. L. and Eisterhold, J. C., 1983. Schema theory and ESL reading pedagogy. TESOL Quarterly, 17(4), pp. 553-573. Available at: https://doi.org/10.2307/3586613, [Accessed: 16 November 2018].

Grabe W., 1991. Current developments in second language reading research. TESOL Quarterly, 25(3), pp. 375-406.

Grabe, W. and Stoller, F. L., 2002. Teaching and Researching Reading. London: Pearson Education Longman.

Graham, L. and Bellert, A., 2009. Reading comprehension difficulties experienced by students with learning disabilities. Australian Journal of Learning Disabilities, 10(2), pp. 71-78. Available at: https://doi.org/10.1080/19404150509546791, [Accessed: 18 August 2018]. 
Gunning, T. G., 1996. Creating Reading Instruction for All Children. Chapter 6, pp. 192-236. Available at: https://eric.ed.gov/?id=ED393073, [Accessed: 21 August 2018].

Hidayati, D., 2018. Students Difficulties in Reading Comprehension at the First Grade of SMAN 1 Darussalam Aceh Besar. B. A. Dissertation, ArRaniry State Islamic University, Darussalam -Banda Aceh.

Karanja, W., 2015. Effects of Reading Difficulties on Academic Performance among Form Three Students in Public Secondary Schools, Kiambus County, Kenya. M. A. Dissertation, School of Education, Kenyatta University, Kenya.

Lau, K., 2006. Reading strategy use between Chinese good and poor readers: a think-aloud study. Journal of Research in Reading, 29(4). Available at: https://doi.org/10.1111/j.1467-9817.2006.00302.x, [Accessed: 20 August 2018].

Lau, K. and Chan, D. W., 2003. Reading strategy use and motivation among Chinese good and poor readers in Hong Kong. Journal of Research in Reading, 26(2). Available at: https://doi.org/10.1111/14679817.00195, [Accessed: 16 October 2018].

Lewis, P. M., Simons, G. F., and Fennig, C. D. (eds.)., 2015. Ethnologue: languages of the world. 18th edn. Dallax, TX: SIL International. Available at: http://www.ethnologue.com, [Accessed: 19 June 2018].

Liu, I., 2011. Chinese language proficiency test becoming popular in Mexico. Available at:

http://www.xinhuanet.com//english2010/china/201106/27/c 13951048.htm, Visited on 12.08.2018, [Accessed: 12 December 2018].

Narayana, S., Jacks, A., Robin, D. A., Poizner, H., Zhang, W., Franklin, C., Liotti, M., Vogel, D. and Fox, P. T., 2009. A Non-Invasive Imaging Approach to Understanding Speech Changes following Deep Brain Stimulation in Parkinson's Disease. American Journal of Speech-Language Pathology. 18(2), pp. 146-161. Available at: https://doi:10.1044/10580360(2008/08-0004, [Accessed: 18 December 2018].

Savic, V., 2015. Reading difficulties in English as a Foreign Language. Ph.D Thesis, Faculty of Arts, University of Novi Sad. Available at: http://nardus.mpn.gov.rs/bitstream/handle/123456789/8156/Disertacija 9371.pdf, [Accessed: 11 January 2018] 
Shirin, S. E., 2012. Reading Strategies of Iranian Postgraduate English Students Living at ESL Context in the first and Second Language. Proceedings of the International Conference on Education and Management Innovation, IPEDR, 30, pp.195-199.

Scott, J. A., Jamieson-Noel, D., and Asselin, M., 2003. Vocabulary instruction throughout the day in twenty-three Canadian upperelementary classrooms. The Elementary School Journal, 103(3), pp. 269283. Available at: https://doi:10.1086/499726, [Accessed: 10 January 2019].

Spencer, W. A., 2015. Mandarin Chinese as a Second Language: A Review of Literature, Honors Research Projects submitted to The University Of Akron. Available at:

http://ideaexchange.uakron.edu/honors research_projects/210, [Accessed: 20 January 2019].

Verghese, P. C., 2009. Teaching English as a second language. 9th edn. New Delhi: Sterling Publishers.

Watts, S. M., 1995. Vocabulary instruction during reading lessons in six classrooms. Journal of Reading Behavior, 27(3), pp. 399-424.

Xiaohong Weng, X., 2009. Teaching Listening and Speaking: An Interactive Approach. In Everson, M. E., Cheng, X. Y. and Tsui. eds., Teaching Chinese as a Foreign Language: Theories and Applications. Cheng \& Tsui Company.

Zhang, L. J. and Anual, S. B., 2008. The Role of Vocabulary in Reading Comprehension: The Case of Secondary School Students Learning English in Singapore. RELC Journal, 39(1). Available at:

https://doi.org/10.1177/0033688208091140, [Accessed: 23 February, 2019].

Zhao, A., Dynia, J. and Guo, Y., 2013. Foreign Language Reading Anxiety: Chinese as a Foreign Language in the United States. The Modern Language Journal, 97(3), pp. 764-778. Available at:

https://www.jstor.org/stable/43651704, [Accessed: 23 February 2019].

Zhou, J., 2017. Foreign language reading anxiety in a Chinese as a foreign language context. Reading in a Foreign Language, 29(1), pp. 155-173. 


\section{To cite this article:}

Eze, V.C., \& Ejiofor, O.S., 2019. Problems of Reading Comprehension in Learning Chinese As A Second Language Among Undergraduates of Chinese Studies in Nnamdi Azikiwe University, Awka, Nigeria. Exchanges: The Interdisciplinary Research Journal, 7(1), 15-36. Retrieved from: http://doi.org/10.31273/eiri.v7i1.451.

\section{Endnotes}

\footnotetext{
' Second language acquisition

ii Any non-native spoken, acquired second language

iii 15-16 years old

iv English as a foreign language

$\checkmark \sim 12-13$ years old

${ }^{\text {vi }} \mathrm{n}=114$

vii $n=76$

viii Nnamdi Azikiwe University
} 